\title{
Pioneering Price Level Targeting: The Swedish Experience 1931-1937
}

\author{
Claes Berg ${ }^{*}$ a and Lars Jonung ${ }^{*} \cdot \mathrm{b}$

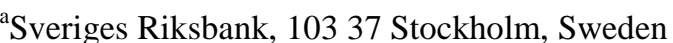 \\ ${ }^{\mathrm{b}}$ Stockholm School of Economics, Box 6501, 11383 Stockholm, Sweden
}
SSE/EFI Working Paper Series in Economics and Finance No 290 December 1998

\begin{abstract}
In September 1931, Sweden became the first country to make the stabilization of the domestic price level the official goal of its monetary policy, actually the only country that so far has adopted such an explicit price level target. Starting from the issues and concepts familiar from research and policy experience of inflation targeting - as contrasted to price level targeting - this paper examines the evolution of the Swedish price level targeting in the 1930s. We bring out a number of similarities and differences between price stabilization in the 1930 s and in the 1990s.
\end{abstract}

Key Words: Price level stabilization; Inflation targeting; Monetary policy; Knut Wicksell; Sweden

JEL Classification: E52; E58; E31

*Corresponding author

Claes Berg: e-mail: claes.berg@riksbank.se/Fax: +46 82105 31/Phone:+46 87870000

Lars Jonung: e-mail: lars.jonung@hhs.se/Fax +46 83132 07/Phone:+46 87369000 


\title{
Pioneering Price Level Targeting: The Swedish Experience 1931-1937
}

\author{
1. Introduction ${ }^{1}$
}

When Sweden left the gold standard in the fall of 1931, the government, under the influence of the economics profession, introduced a monetary program of stabilization of the domestic price level. It was launched at the onset of the depression, initially to arrest the fall in prices as well as mitigating widespread fears of rising prices. The monetary declaration of 1931, consisting of one sentence, evolved in several steps into a full monetary program before it was finally approved by the Parliament, the Riksdag, in $1932 .^{2}$

The Swedish experience of the 1930s anticipated much of present discussion of monetary policy for central banks with price stability as the primary objective. ${ }^{3}$ The Swedish policymakers took aboard the idea, familiar from inflation targeting countries today, that an institutional commitment to price stability could act as a coordinating device and anchor expectations. The Riksdag and its Banking Committee supervised and monitored the activities of the Riksbank through regular reports. The Governor was questioned annually by the Banking Committee. Monetary policy was evaluated in bills put forth by the government. The monitoring of the Riksbank occurred through an open political process well covered by the press. Two major evaluations of the monetary program were carried out, in 1933 and 1937, in addition to the annual examinations by the Banking Committee. The transparency of the monetary policy strategy in the 1930s through communication with the Swedish public can be seen as anticipating the modern view on inflation targeting.

Central banks pursuing an inflation target today have all announced a numerical target for inflation. The Riksbank published from 1931 and onwards a weekly consumer price index as

\footnotetext{
${ }^{1}$ We would like to thank Lars E.O. Svensson for many constructive comments. We are also grateful to Michael D. Bordo, Benny Carlson, Klas Fregert, Mervyn King, Carl-Göran Lemne and the referee for helpful advice. Jesper Hansson and Lena Lindhe has skillfully assisted with the construction of the figures. We also thank AnnChristine Högberg för secretarial and editorial assistance.

${ }^{2}$ The Swedish monetary program of the 1930s as well as the work on monetary rules by Swedish economists like Knut Wicksell, David Davidson and Erik Lindahl attracted a considerable interest internationally in the 1930s. See Fisher $(1935,1937)$ and Lester (1939) among others. It was "rediscovered" as part of the impact of monetarism and of monetary history in the Friedman and Schwartz (1963) spirit in the 1970s, see Jonung (1979b, 1981). The present debate on inflation targeting and on rules versus discretion has contributed to a new interest in the Swedish 1930s. See for example Johnson and Keleher (1996).

${ }^{3}$ For surveys on the inflation targeting of the 1990s see Haldane (1995), Leiderman and Svensson (1995) and Bernanke and Mishkin (1997) among others.
} 
part of the monetary policy process. However, the consumer price index was not the sole target variable. The Riksbank monitored other price indices as well. Nevertheless, it was concerned with "underlying inflation" in a modern way, as it stressed the need to disregard temporary factors, like indirect taxes, customs duties and seasonal effects, influencing the development of inflation.

The price stability target adopted by the Riksbank in 1931-32 was a price level target, in contrast to the inflation targets adopted by several central banks in the 1990s. With a price level target the longer-term variance of the price level, and hence uncertainty, are smaller. According to Fischer (1994), the chief disadvantage of a price level target is that the monetary authority is attempting to deflate the economy half the time, thus creating more uncertainty about short-term inflation rates than with an inflation target. However, in a model with persistence in output (due to price-stickiness, for instance), price level targeting results in lower short-run inflation variability than with inflation targeting. ${ }^{4}$

This paper analyzes the evolution of the Swedish experiment of price level targeting in the 1930s. ${ }^{5}$ When discussing Swedish monetary policy in the 1930s we are interested in a number of issues associated with modern views on inflation targeting and central bank policies. Which political body introduced the target for monetary policy? How was price stability operationally defined by the Swedish authorities? Which price indices were used? How was the target date set? Was the Riksbank given instrument independence? Which was the role of public announcements to influence expectations by the public? Were there any changes in central bank legislation? Did monetary aggregates play a role in the design of monetary policies? How was the program of price stabilization monitored by the Parliament and other observers? Was the Riksbank held accountable for the behavior of prices and other economic variables? Are there any lessons for the implementation of inflation targeting today? Is there anything essential in today's inflation targeting that was overlooked by the Riksbank in the 1930s?

We turn to these questions below.

\footnotetext{
${ }^{4}$ Under inflation targeting, according to the model by Svensson (1997b), the decision rule is a linear feed-back rule for inflation on the output gap and the variance of inflation is proportional to the variance of the output gap. Under price level targeting, the decision rule is a linear feed-back rule for the price level on the output gap. Then inflation is a linear function of the first difference of the output gap and the variance of inflation is proportional to the variance of the first difference of the output gap.

${ }^{5}$ Ohlin $(1933,1934)$ and Lester (1939) used the term experiment pertaining to the monetary program in the 1930s to stress the novelty of the price stabilization program.
} 
2. The adoption of the monetary program of price stabilization 1931-32

\subsection{Forces behind the adoption}

Why was price stabilization adopted as the guide for Swedish monetary policy in 1931? Two major forces were at work here: first, the influence of the economics profession on policymakers due to its strong position in Swedish society, and, second the monetary experience of World War I and of the 1920s of high inflation and sharp deflation as interpreted by contemporary observers.

The academic economists provided a major source of inspiration. In 1898 Knut Wicksell presented for the first time in Sweden the view that price level stabilization should be the proper guide for central bank policy. According to Wicksell's monetary rule or norm, see Wicksell (1965), the central bank should raise its discount rate as long as prices were rising, lower it as long as prices were falling and keep it constant when the price level was stable. The key to price stabilization was thus found in the discount rate. This was the essence of the "cumulative process" as Wicksell's theory was later termed. Price stabilization was thus accomplished by interest rate policy.

The economists held a strong position in public debate in Sweden, highly respected and successful in a way difficult to comprehend today. ${ }^{6}$ Gustav Cassel had his greatest impact in the 1920s, being regarded as the most influential economist in the world before being eclipsed by John Maynard Keynes in the 1930s. An American observer noted that the Swedish public became "price-level minded" due to the energetic journalistic activity of the economists. ${ }^{7}$ The strong position of the economics profession eventually paved the way for the adoption of the monetary program of 1931 .

The second major force accounting for the price stabilization program was the monetary experience after World War I. The output losses during the deflation process in the early 1920s and the world-wide depression starting in 1928 undermined the legitimacy of the gold standard within Sweden. When the depression hit Sweden in 1931 the ground was laid for the search and acceptance of alternatives to the gold standard. The depression became in this way a window of opportunity for the proponents of price stabilization.

\footnotetext{
${ }^{6}$ The lively journalistic activities of the first generation of Swedish economists are described in Magnusson (1993).

${ }^{7}$ See Lester (1939, p. 226), where he also stated: "In Sweden academic economists probably enjoy more respect and influence with the people and the government than anywhere else in the world."
} 


\subsection{The program of 1931}

The full impact of the depression hit Sweden in 1931 through a fall in exports and a drain on its foreign reserves. Bank failures in Central Europe contributed to capital outflows from Sweden. When the Bank of England made its notes inconvertible to gold on September 19, 1931, speculators attacked the krona.

In anticipation of a request by the Board of the Riksbank for permission to make Riksbank notes inconvertible into gold, the Minister of Finance, Mr Felix Hamrin, turned to Gustav Cassel on Saturday September 26. Cassel was asked to prepare a statement concerning the monetary position of Sweden to be used by the Government. ${ }^{8}$ He accepted, toiling with this task well into the night, sending his proposal to Hamrin by messenger late Saturday.

In the declaration made public Sunday evening, the Minister of Finance first explained the chain of events leading to the decision of gold suspension. At the end of the declaration, the monetary program of price stabilization was announced; the domestic purchasing of the krona should be preserved "using all means available". 9 Apparently it was an economist, Gustav Cassel, who was instrumental in putting price stabilization into the announcement of the Swedish government. ${ }^{10}$

\subsection{The program of 1932}

The new monetary policy goal was covered by one sentence in the declaration of September 27th, 1931, Thus, it was far from a complete program for monetary policy. It became the starting point for eight months of deliberations by the Board of the Riksbank, for reports by three leading monetary economists, for work within the Banking Committee of the Riksdag that supervised the Riksbank, and for public debate on monetary issues - before a more fullfledged program was finally confirmed by the Riksdag in May 1932. This program can be summarized in five major points:

\footnotetext{
${ }^{8}$ From 1931 until 1974, the Riksdag granted annually the Riksbank exception from the requirement of redeeming its notes into gold. In 1974 the constitution was changed, cutting the link between gold and Riksbank notes. This step marked the end of the gold standard in Sweden from a purely legalistic point of view. The gold suspension of 1931 was the first and only occasion when the notes of the Riksbank were made inconvertible in a legal sense; all other suspensions have been illegal. See Fregert and Jonung (1996).

${ }^{9}$ Record of financial matters, done before the King-in-Council at Stockholm Palace on 27th September 1931.

${ }^{10}$ The above description is taken from the autobiography by Cassel (1941, p 285). Cassel noted that Hamrin did not show him any appreciation for this work. We cannot rule out that Hamrin used other advisors as well. Lester (1937, 1939) stated that Heckscher prepared Hamrin's statement. Most likely, Hamrin was influenced by both Cassel and Heckscher. The full account of the monetary program of 1931 remains to be written. See Jonung (1979a, 1979b) on the adoption of the monetary program.
} 
1) An immediate return to gold or a peg to the British pound should not to be considered, that is Sweden should maintain a flexible exchange rate for the krona for the time being. Efforts to control the value of the krona should start from the domestic price level and the "needs of Sweden's economy".

2) Continued deflation should be resisted just as strongly as the inflation - that was expected when Sweden abandoned the gold standard - was resisted.

3) Some recovery in prices would be desirable, though not a return to a "too distant" price level. Even domestic prices should be allowed to rise, not just export and import prices, provided this did not appreciably affect the cost of living. Price increases due to higher custom duties should be accepted as consistent with the monetary program.

4) Monetary policy should not be tied schematically to a particular index figure. Conducting monetary policy in the interest of the entire country involved considering so many factors that "a formal and simple rule" for monetary policy did not appear feasible.

5) It was generally desirable that domestic interest rates were kept as low as was conceivably possible without jeopardizing the monetary policy objective.

In June 1933 the Riksdag approved a revised version of the monetary program. The major additional recommendation - giving instrument independence to the Riksbank - was stated in the following way:

6) The choice of means for reaching the monetary policy objective should rest entirely with the Riksbank, and the Riksbank should be allowed such liberty of action as is required for this purpose.

By this program, Sweden became thus the first country to make the stabilization of the level of domestic prices the official goal of its monetary policy; actually the only country that did so in the interwar period. According to contemporary economists, Sweden adopted Knut Wicksell's program or norm of price stabilization. In modern parlance, the Riksbank became the first central bank to introduce price level targeting explicitly. To our knowledge it remains the only central bank that has taken such a step so far.

\section{Swedish Economic Performance in the 1930s}

As the evolution of the monetary program and the evaluation of the program were strongly influenced by actual economic events, we describe briefly the behavior of some major economic aggregates such as prices, interest rates, exchange rates, unemployment and production in the 1930s prior to World War II.

Prices. Much of contemporary discussion of the monetary program focused on the consumer price index of the Riksbank and on the wholesale price index. These two indices, displayed in 
Figure 1 for the period 1928-38 with September 1931 as the base equal to 100, show roughly the same long-run pattern, falling from 1928 until 1932-33 and then turning upwards. (The consumer price index is proxied by the cost-of-living index for 1928-30 in Figure 1.) The secular fall and rise in consumer prices, however, is much smaller than the movements in wholesale prices.

Wholesale prices fell sharply from January 1928 to September 1931, reflecting the effects of the international deflation transmitted to Sweden through the workings of the interwar gold standard. The deflationary process was halted by Sweden leaving the gold standard and adopting a "free" standard in September 1931 - as envisaged in Hamrin's declaration of September 27th, 1931. Wholesale prices subsequently remained roughly constant, with a minor decline, until the spring of 1933. From then on they began a gradual rise, accelerating in 1936-37, then falling in 1937-38.

Judging from Figure 1, the consumer price index exhibited a stable long-run pattern. It declined on average in 1931-33 followed by a gradual rise from then on. The index fluctuated considerably less than wholesale prices within a band of less than 3 percentage points around the base level of 100 for September 1931 during the period 1931-36. In 1937 consumer prices rose by almost 5 per cent, then remaining stable prior to the outbreak of World War II.

Exchange rates. Contemporary commentators on monetary matters paid much attention to the behavior of exchange rates. Actually, the protocols from the meetings of the Board of the Bank reveal that the Bank was preoccupied primarily by the behavior of the pound rate but also of the dollar rate. The pound rate, as shown in Figure 2, fell below the gold parity rate of 18.15 kronor during the fall of 1931. It rose sharply above the gold parity rate at the news of the death of Ivar Kreuger in early March 1932, declining in the Fall of 1932. After a rise in the Spring of 1933, the Riksbank pegged the krona to the pound in July 1933. The peg was maintained until the outbreak of World War II, demonstrating Sweden's adherence to the Sterling bloc that evolved after the gold suspension of 1931 by the Bank of England. ${ }^{11}$

The dollar rate rose sharply after Sweden left gold, reached a peak in the Fall of 1932 and fell back almost to the gold parity level after the US left the gold standard in the Spring of 1933.

Interest rates. Swedish interest rates followed relatively closely the UK rate as seen in Figure 2. When the link between the krona and gold was severed in September 1931, the Riksbank raised its discount rate from six to eight per cent out of fear of inflation. It was subsequently

\footnotetext{
${ }^{11}$ The Scandinavian countries as well as members of the British empire among other countries belonged to the Sterling bloc or Sterling area in the 1930s.
} 
lowered, albeit at a slower pace than the UK rate, reaching 2,5 per cent in 1934 where it remained until the outbreak of World War II.

Unemployment and production. The rate of unemployment rose sharply starting in 1930-31, peaking in the Spring of 1933, see Figure 3. Unemployment remained high, although falling, during the rest of the 1930s. Production, in particular within the export sector, declined sharply during the depression. Real income fell in absolute terms during two years, 1932 and 1933.

Compared to most other countries, in particular those that stayed on gold, the Swedish economy fared relatively well during the 1930s. ${ }^{12}$ While industrial production, as shown in Figure 3, fell by 21 per cent in Sweden in 1929-32, the decline in the US was 46 per cent. The corresponding numbers for the decline in real income are 9 and 22 percent, respectively. ${ }^{13}$ The Swedish recovery in 1933-38 was remarkably strong as well.

\section{The Evolution of the Monetary Program 1931-37}

The Riksbank was facing a new task after the gold suspension in September 1931; that of implementing a program of price stabilization. It had no prior experience, nor any foreign examples to use as guidance. It simply lacked knowledge about the proper conduct of monetary policy under a "free standard" - as Swedish commentators described the new monetary regime. At the suggestion of Ivar Rooth, the Governor of the Riksbank, the Board of Directors decided on October 8, 1931 to turn to three renowned economists, Gustav Cassel, David Davidson and Eli Heckscher, for advice. They each received a questionnaire from the Riksbank. See Table 1 displaying the questions.

The questions were sorted under three major headings. First, the proper choice of monetary standard for Sweden and the transition to such a standard, second, the proper set of instruments (or means) for monetary policy, and third and finally, any other issues deemed important for the future organization of the monetary system of Sweden. As the recommendations, given in three separate reports, of the three economists covered most of the issues that were debated subsequently, they are refered to frequently below in our account of the evolution of the monetary program. In addition, the reports most likely influenced the Riksbank in the 1930s. The views of the three economists, in particular those of Cassel and

\footnotetext{
${ }^{12}$ This is a common pattern during the 1930s; countries leaving gold early were hit less severe by the depression. See for example Eichengreen (1992) and Bernanke (1995).

${ }^{13}$ See Table 1 in Jonung (1981).
} 
Heckscher, became well known to the public through newspaper articles and other contributions.

4.1. Was the shift to price level targeting a permanent or a temporary one?

In the 1990s the adoption of inflation targets in several countries has been announced as a permanent shift of the monetary policy regime, commonly as a reaction to disappointment with the macroeconomic performance of the old regime. Inflation targeting thus represents a move from regimes based on fixed exchange rates, monetary targeting or high inflation to a regime of low inflation or price stability as defined as an annual inflation rate within a range from zero to 3 percent annual inflation. Much effort has been spent at creating credibility for the new regime of inflation targeting and reducing expectations of return to high inflation. ${ }^{14}$

The introduction of the price level target in 1931 was initially viewed as a temporary - not a permanent - step by the Swedish policy authorities. When the Minister of Finance announced the new monetary policy goal on 27 September 1931, he declared that the divorce from gold was not to be a permanent one. On the contrary, a return to gold should be aimed for as soon as the conditions for this were at hand. ${ }^{15}$

About a month later in their replies to the questionnaire of the Riksbank on the future monetary arrangement of the krona, Cassel, Davidson and Heckscher were of the same opinion. The three economists recommended that Sweden should maintain a "free standard" based on price stabilization as long as the world monetary system remained disorganized. There should be a rapid and immediate return at existing exchange rates to a gold standard or to an international monetary system, once international monetary stability had been restored.

The permanence of the program was considered a few months later by the Banking Committee in February 1932; " It should be pointed out that at present any monetary policy program must be said to apply only for the time being." ${ }^{16}$ In a similar vein, the Banking Committee declared in May 1932; " the statements, with which the Government concurs in these respects, could no doubt acquire the character of guidelines for our monetary policy in the immediate future."17

\footnotetext{
${ }^{14}$ See for example the contributions in Leiderman and Svensson (1995) on the inflation targeting in five countries.

${ }^{15}$ Record of financial matters, done before the King-in-Council at Stockholm Palace on 27th September 1931.

${ }^{16}$ Banking Committee, Submission 6, February 1932, p. 3, italics are ours.

${ }^{17}$ Banking Committee, Submission no. 40, May 1932, p. 15, italics are ours.
} 
However, as the international gold standard gradually dissolved in the 1930s, it became obvious that a return to gold was no longer a viable alternative for Sweden. Instead, the monetary program was maintained and gradually amended in various ways. Some economists actually started to view it as the first step towards a Swedish as well as an international adoption of price stabilization as the proper norm for monetary policy - as an alternative to fixed exchange rate systems. This was the case of Irving Fisher (1935) and Erik Lindahl (1937).

\subsection{How was price stabilization defined?}

In the 1990s countries pursuing an explicit price stability target have chosen an explicit quantitative inflation target, either an interval or a point target, where the center of the interval or the point target varies across countries from 1.5 to 2.5 per cent per year. The target, thus, is set in terms of a rate of change rather than of the price level. Several recent papers present arguments for preferring a target in terms of levels rather than rates of change, however. ${ }^{18}$

The price stability target adopted by the Riksbank in 1931-32 was a price level target, in contrast to the inflation target adopted by central banks in the 1990s. A price level target implies that a lower than target inflation rate in one period has to be offset by a correspondingly higher inflation rate in the following period. An inflation target allows "base drift" in the price level: after each period, the actual price level is taken as the base for the inflation target of the next period, even if the inflation target for the base period was not met.

When the Finance Minister announced that monetary policy should be directed at "preserving the domestic purchasing power of the Swedish krona" in September 1931, he wanted to arrest the ongoing deflation as well as calm fears of inflation judging from contemporary comments. It was left to others to select the norm consistent with "stable domestic purchasing power". At that time two alternatives existed: either the norm of Wicksell, that is of a stable price level, or the norm of Davidson, that is a falling price level proportional to productivity growth. ${ }^{19}$ Both norms are consistent with the concept of "price stabilization" - just as a low rate of inflation today is consistent with the concept of "price stabilization".

The three economists all agreed that monetary policy under a paper standard should be focused solely on price stabilization. They did not consider any other goals for the Riksbank

\footnotetext{
${ }^{18}$ See Dugay (1994), Fischer (1994), Goodhart and Vinals (1994), and Svensson (1997b).

${ }^{19}$ The norm proposed by David Davidson and later advanced by Erik Lindahl is analyzed using modern methodology by Fregert (1993).
} 
such as output or employment stabilization in their reports although written when Swedish industrial production was declining and unemployment was rising dramatically.

Judging from the official documents on monetary policy during the subsequent years, price stabilization was eventually defined as price level targeting. In April 1932 the Governing Board of the Riksbank stated that it was expected that in the first place, as in other countries, the departure from the gold standard would start a process of inflation. The declared monetary policy program was "intended to calm such fears". On the other hand, the Board said, "the program was intended to prevent the price level in Sweden from following the downward international price trend". ${ }^{20}$

In May 1932, the Banking Committee considered criticism that had been directed at the monetary policy program. The Committee thought that the critical opinions could be reconciled with the broad guidelines of the program in case the Governing Board's statement is elaborated such that an "equally strong defence is set up against continued deflation as against an originally feared inflation and that the price recovery referred to is not envisaged as a return to an unduly distant price level." ${ }^{21}$ The Banking Committee stated in May 1932 that the starting point for a policy to control the value of the krona should be "the domestic price level and the needs of Sweden's economy". ${ }^{22}$ To sum up, price stabilization was eventually regarded as synonymous with Knut Wicksell's norm of stabilizing the domestic price level.

\subsection{Which price index was used as target variable?}

In the 1990s countries basing their monetary policy on an explicit, quantitative inflation target have chosen the consumer price index or a variant of this excluding volatile components as the target variable. In some countries the target variable disregards effects of political decisions (taxes and subsidies) or of monetary policy decisions. Alternatively, a number of factors that should be disregarded in evaluations of the target variable are specified in advance. $^{23}$

\footnotetext{
${ }^{20}$ The Board of Directors in a document dated 14 April 1932, cited in Banking Committee, Submission no. 40, May 1932, p. 13, italics are ours.

${ }^{21}$ Banking Committee, Submission no. 40, May 1932, p. 18, italics are ours.

${ }^{22}$ Banking Committee, Submission no. 40, May 1932, p. 17, italics are ours.

${ }^{23}$ In New Zealand, for example, the types of shocks that are disregarded are specified in the agreement between the Ministry of Finance and the Central Bank, which explicitly refers to e.g. significant changes in terms of trade.
} 
In the 1930s the Swedish authorities were facing the choice of the proper price index to select as the target variable for the new monetary program. In his reply to the Riksbank questionnaire, Heckscher settled eventually for the price of goods domestically produced. According to Cassel, the choice was between the stabilization of either the wholesale prices or of the cost of living. Cassel argued that the public would favorably receive the stabilization of the cost of living. Davidson suggested that "due attention" should be given to every kind of price index since so little was presently known about this issue. The Bank ought to use its price data for two purposes, first, and most importantly, to measure the impact of monetary policy and, second, to inform the Bank about future developments, that is to use it as an indicator.

The Riksbank started to calculate a consumer price index on a weekly basis after the announcement of the price stabilization norm in the autumn of 1931. The consumer price index was constructed at the statistical office at the Riksbank assisted by the Board of Trade and the Royal Social Board. ${ }^{24}$ See Figure 1 . However, the Riksbank did not tie its policy solely to its consumer price index. In February 1932, the Board of the Riksbank pointed out that "other price indices besides the Riksbank's own index of consumer prices will also be taken into consideration." 25 This citation clearly indicates that the Board did not want the price norm to be formulated only in terms of the consumer price index. The explicit role of indirect taxes when calculating the index figures was also taken into consideration. ${ }^{26}$

According to Lindahl (1933), allowable divergences were alterations in indirect taxation, seasonal price changes and other changes of the consumption price level which were not conditional upon the construction of the index number but were of a more fundamental character. ${ }^{27}$ The Board of the Riksbank also stated that, in its endeavor to create as stable economic conditions as possible, it was also taking into account other factors than mere changes in the price level, particularly conditions affecting productivity and stocks in various industries.

Finally, the Banking Committee, in May 1932, formulated the part of the program concerning monetary policy indices, that was to be accepted by the Parliament:

\footnotetext{
${ }^{24}$ Information on the consumer price index is from Lindahl (1933).

${ }^{25}$ Banking Committee, Submission 6, February 1932, p.2-3, italics are ours.

${ }^{26}$ See Banking Committee, Submission no. 40, May 1932, p. 14.

${ }^{27}$ In fact Lindahl calculated a measure of the consumer price index adjusted for seasonal factors and indirect taxes, see Lindahl (1933).
} 
"In this context it should be underscored that monetary policy should not be rigidly bound by a particular index figure, neither did the Governing Board appear to intend this. In the endeavor to conduct monetary policy in the interest of the entire country, so many factors have to be considered that one can hardly have a simple and formal rule." 28

To conclude: On the recommendation of the economists, the Riksbank constructed a consumer price index in order to analyze at short intervals (it was a weekly index) the influence of monetary policy on the internal purchasing power of the krona. This index enabled the public as well as the directors of the Bank to draw conclusions as to the future development of the price level as stressed by Davidson and Heckscher. ${ }^{29}$ The Riksbank also monitored the wholesale price indices published by the commercial banks and the Royal Board of Trade, as well as the price series relating to raw materials. The Riksbank was concerned with temporary factors, like indirect taxes, and seasonal effects, influencing the development of inflation. In many ways, the discussion in 1931-32 is a forerunner to the analysis of measures of the underlying rate of inflation in countries pursuing an inflation target strategy today.

\subsection{At which level and date should price stabilization start?}

In January 1993 when the Riksbank announced its adoption of an inflation target, it also declared a transition period of two years by stating that the inflation target was to be effective starting in January $1995^{30}$. The Riksbank specified that the objective of monetary policy is to limit the annual increase in the consumer price index in 1995 and onwards to 2 per cent, with a degree of tolerance of \pm 1 per cent. This objective corresponded to the underlying rate of inflation when the target was announced. In 1993 and 1994 monetary policy was to aim at preventing the inflationary impulse due to the depreciation of the krona and changes in indirect taxes from causing an increase in the underlying rate of inflation. Thus the Riksbank did not suggest a particular level of the CPI as the starting point of inflation targeting, it referred rather to the underlying inflation as a form of a nominal anchor during the interim period.

In September 1931 when the krona was divorced from gold, prices had been falling since 1928 - see Figure 1. The discussion therefore centered on the issue of an appropriate level at which prices should be stabilized. A major question was the following one: which point of time should be chosen as the base for the program of price stabilization? Heckscher settled for the average price level of the third quarter of 1931 . He argued that a return to the price level of 1928-29 - before the fall in prices - was not to be recommended on two counts; first, the

\footnotetext{
${ }^{28}$ Quoted from Banking Committee, Submission no. 40, May 1932, p. 18-19, italics are ours.

${ }^{29}$ This was noted by Fisher (1934, p. 408).

${ }^{30}$ See Andersson and Berg (1995).
} 
inflation required for such a purpose would create requests for higher nominal wages, perhaps giving rise to an increasing real wage, second, and most important, it was extremely difficult to manage a free standard when prices were rising since rising prices would contribute to speculation about future prices.

Should monetary policy aim at changing the relationship between various indices, particularly between the wholesale price index and the cost-of-living index? Heckscher answered in the negative. As monetary policy could not do anything in this field, the Riksbank should ignore any disparate movements of individual indices in the past.

In Cassel's opinion, wholesale prices and the cost of living price index had to converge before any stabilization could take place. He stressed that the wholesale price index had declined by 25.6 per cent from the average level of 1928 to July 1931 while the cost-of-living index had declined by only 8.7 per cent in the same period. A slight rise in wholesale prices was the best way to accomplish convergence between the two series, as a lowering of the cost of living would reduce nominal wage rates and cause social unrest. Thereafter a stabilization of the cost of living at the level prevailing in mid-1931 would be preferable, according to Cassel.

The relationship between wholesale and consumer prices as discussed by the economists remained an issue throughout the 1930s. In January 1932 the Finance Minister repeated that the aim should still be to maintain the purchasing power of the krona. However, he also noted that "this, of course, does not preclude certain modifications of prices, especially wholesale prices." ${ }^{31}$

The intention of the Board of the Riksbank was to maintain more or less unaltered the average level of prices of domestic and consumer goods. A monetary policy along these lines was compatible with a minor rise in the Riksbank's index as prices of certain import and export goods were expected to increase. The Banking Committee then added that even domestic market prices should be allowed to rise, not just export and import prices, provided this did not appreciably affect the cost of living. This can be interpreted as a provisional short-term specification of a price stability target, in the long run aiming at price stability. The reason for this interpretation is that wholesale prices since 1928 had fallen much more than retail prices.

These intentions together with the idea, also supported by the Banking Committee, that it was desirable to keep domestic interest rates as low as possible without jeopardizing the monetary policy objective ${ }^{32}$, can be seen as an attempt to reduce the commitment to price stability. Given the world-wide depression and the process of ongoing deflation in many countries at

\footnotetext{
${ }^{31}$ Finance Minister quoted in Ohlin (1932, p. 3), italics are ours.

${ }^{32}$ See Banking Committee, Submission no. 40, May 1932, p. 19.
} 
the time when the Swedish monetary program was designed, it is proper to interpret these modifications of the target as responses to major shocks; in mid 1932 there was a clear concern of continued deflation.

The idea of a lagged or gradual introduction of the new monetary program did not occur in the 1930s. Price stabilization was to take place at once. As policies emerged the September 1931 price level was adopted as the starting point although various requests were made in the following years for a rise in the wholesale price index.

\subsection{Who should set the goal and instruments of monetary policy?}

Modern research on central bank independence draws a distinction between goal independence and instrument independence. ${ }^{33}$ A central bank has goal independence when it is free to set the ultimate goals for monetary policy (e.g. decide that price stability is less important than output stability). A central bank has instrument independence when it can freely choose the means by which it seeks to achieve its goals. To examine the issue of goal and instrument independence in the 1930s, we focus on the process leading to the approval of the monetary policy program by the Riksdag.

The Riksbank has been the bank of the Parliament since 1668 when it was taken over from private interests. The Parliament traditionally protected the Riksbank from attempts by the executive branch to take control over monetary policy prior to the advent of parlamentarism. With the acceptance of parlamentarism, the majority of the Riksdag appointed the cabinet (the government) as well as the Board of the Riksbank. In this way, Parliament determined the final goals for the Riksbank. The Riksbank was thus goal dependent in the 1930s.

The Banking Committee of the Parliament forcefully reminded the Bank of its goal dependence in May 1932:

"The Committee's starting point is that the broad guidelines for monetary policy are established by the Government, not by the Board of Governors, and that maintaining the convertibility of notes for gold has accordingly been the guiding principle for the Riksbank's managerial body. ..." 34

\footnotetext{
${ }^{33}$ Debelle and Fischer (1994).

${ }^{34}$ Banking Committee, Submission no. 40, May 1932, p. 15, italics are our.
} 
The first evaluation of the monetary policy program approved by the Riksdag was published in June 1933. The most important new aspect was the following statement, arguing for giving instrument independence to the Riksbank:

"The Riksbank should be given no directions as to its monetary policy beyond those that spell out the objectives of that policy. The choice of means for reaching this objective should rest entirely with the Riksbank, and the Riksbank should be allowed such liberty of action as is required for this purpose. In regard to public fiscal demands on the Riksbank, the latter's complete independence should be maintained." ${ }^{35}$

The monetary policy program finally approved by Parliament implied that the Riksbank became goal dependent but instrument independent.

There was no major change in the legal framework for monetary policy in the 1930s reflecting the switch from the gold standard to a monetary regime based on price stabilization.

Heckscher considered in his report in October 1931 whether any constitutional guarantees should be adopted for the paper standard similar to those once found in the Swedish law pertaining to the gold standard. Heckscher was pessimistic about the feasibility of such guarantees since the paper standard lacked those simple points of references of the gold standard that made it easy to see if the rules of the system were followed. Still, Heckscher was of the opinion that attempts ought to be made to anchor the paper standard in the law, suggesting that in due time it would be possible to find better points of references than those presently available.

One possible approach would be to legally force the central bank to maintain a stable price level according to Heckscher. However, this approach was probably dangerous to adopt for two reasons. First, it would give constitutional status to the weights of a given price index, which would not adjust to continuous changes in the economy. Second, one specific price index was in any case an inadequate point of reference for monetary policy. At best, the law could prescribe some maximum allowable deviations around a fixed level of a price index or of a combination of price indices. However, at this juncture no legal regulations should be introduced.

At any rate, the Swedish authorities should publicly declare their firm commitment to the principles of the new monetary program and preferably also state explicitly that the foreign value of the krona and the volume of notes in circulation would be dependent on the aim of the monetary program. Apparently Heckscher viewed such announcement as a substitute for legislation based on the monetary program and as a method to foster the credibility of the

\footnotetext{
${ }^{35}$ Memorandum by the Swedish Delegation on the Monetary Policy of Sweden (1933, p. 2).
} 
program of price stability. In contrast to Heckscher, Cassel and Davidsson did not suggest any judicial changes in order to establish a binding commitment to the new price stability norm.

\subsection{Which instruments and indicators were chosen?}

Cassel, Davidson and Heckscher agreed that the monetary policy instruments used by the Riksbank in order to fulfil the price stability target remained the same as under the gold standard: changes in the discount rate and operations in the foreign exchange market were the most important instruments. Explicit announcement concerning the primary objective for monetary policy could also serve as an important instrument in order to maintain credibility and confidence in the future value of the krona, as emphasized by Heckscher. ${ }^{36}$

None of the economists did mention the use of monetary aggregates such as the monetary base or the money stock. The three economists were all working within a monetary framework that should be classified as Wicksellian. The discount rate was the important tool of monetary policy. Monetary aggregates played no explicit role as intermediate targets or indicators in this framework

Heckscher argued that movements in wholesale prices should be used for the purpose of making forecasts for directing monetary policy and that fluctuations in retail prices should be adopted as a measure of the actual effects of monetary policy - as a "verification" according to his report.

Present practice of inflation targeting makes substantial use of forecasts, in particular of the future rate of inflation. A striking feature of the price level targeting of the 1930s is the lack of explicit forecasts and prognosis within the Riksbank. Why was this the case? Dag Hammarskjöld (1935) provided one answer in a lecture on modern central banking to the Swedish Bankers' Association in 1935 - at that time he was employed by the Riksbank working in close contact with its Governor Ivar Rooth. Hammarskjöld stressed that in the past when Sweden was on gold, central banking was characterized by the automatic functioning of the gold standard - it displayed the working patterns of a "machine". In this institutional setup there was no need for information about the behavior of the economy.

Under present circumstances it was obvious that central banks needed knowledge "about the domestic business cycle and the world business cycle", however. The modern central bank thus should recruit a new type of employee, namely that of the economic advisor, in charge of

\footnotetext{
${ }^{36}$ Kjellström (1934, p. 36).
} 
analyzing domestic and international economic events according to Hammarskjöld (1935, p. 6). He pointed at the Bank of England as a forerunner in this field. Hammarskjöld's lecture gives a reason why the Riksbank did not use any inflation forecasts. The Bank simply lacked the expertise capable of producing forecasts in the modern sense. The econometric techniques and the statistical data used presently for inflation forecasting did not exist at the time.

\subsection{Did the Riksbank strictly adhere to prize stabilization?}

The Government introduced the monetary program in 1931, eventually getting it supported by Parliament. The program was initially viewed as a temporary one by the Government, the economists and the Riksbank. Throughout its long history the Riksbank had been aiming for a fixed exchange rate for its currency. Price stabilization was a new and unfamiliar goal for the Riksbank, potentially inconsistent with its traditional goal of a fixed rate. Judging from its behavior in the 1930s, the Riksbank regarded a future return to a fixed exchange rate as a natural and proper step.

Immediately after leaving gold, the Riksbank did not intervene in the market for foreign exchanges, instead it allowed the krona to float freely. However, it tried to return to a fixed rate in November 1931 by pegging the krona to the pound at the old gold parity rate. The pegging lasted for three days, then it was abandoned. The Riksbank did not offer an explanation of this failed attempt. It learnt, however, that a return to a fixed rate required substantial foreign reserves. Such reserves were purchased in 1932-33. In July 1933 the Riksbank established a successful peg of the krona to the pound that lasted until the outbreak of World War II. See Figure 2.

The pound pegging of 1933 raises the question to what extent the Riksbank was actually accepting price stabilization as the primary goal for its policy. The fixed pound rate was consistent with price stabilization as long as prices within the Sterling bloc moved in a way consistent with the program of domestic price stabilization which was the case during most of the period 1933-39. The fixed rate was seriously questioned only once. In 1936-37 when British prices rose sharply, Cassel and Heckscher asked for an appreciation of the Swedish krona in order to isolate Swedish prices from the international inflation. The Riksbank decided, however, to maintain the peg. With this exception, the pound pegging was commonly viewed as consistent with the policy of price stabilization. ${ }^{37}$ As events turned out, the monetary program remained officially in force throughout the 1930s although being modified in various ways. It is safe to conclude that the Riksbank was strongly influenced by

\footnotetext{
${ }^{37}$ The policy discussion within the Riksbank in 1937 was well aware of the problem of reconciling a fixed exchange rate with domestic price stability, see Jonung (1979b).
} 
the monetary program, that it tried to adhere to it, but that the Riksbank also wanted to go back to a regime of fixed exchange rates.

\section{Evaluations of the Price Stabilization Program in the 1930s}

The Riksbank was continously monitored by the financial press, the economics profession, the Parliament and the Government. Its policy was thus evaluated by many sources. Here we consider briefly the views of the Government and of prominent economists as they evolved in the 1930s.

\subsection{Official Evaluations in 1933 and 1937}

Aside from the annual examination by the Banking Committee, two major official evaluations of the monetary program were presented in the 1930s. The Minister of Finance presented his first evaluation of the performance of the monetary program in a government bill on 26 May 1933. He was critical of the policy of the Riksbank. The Bank had not fulfilled the goal of monetary policy; both wholesale and consumer prices had fallen between September 1931 and April 1933. The Minister of Finance wanted the Riksbank to intervene "more actively" and to "link" - that is to coordinate - the Riksbank's policy with the Government's fiscal policy to combat unemployment. These formulations reflected the fact that the Finance Minister, Ernst Wigforss, of the Social Democratic government coming into power in 1932, was inspired by the ideas on fiscal policies promoted by John Maynard Keynes in the UK and by Bertil Ohlin and Gunnar Myrdal in Sweden. ${ }^{38}$

The second evaluation of the monetary policy program was made public in 1937 . The Minister of Finance noted that the depression had given way to a pronounced boom. The price fall had been succeeded by a price rise that proceeded slowly in the early years within narrow limits but had accelerated markedly since the preceding autumn, so that wholesale prices were close to the level before the outbreak of the depression. ${ }^{39}$

Ernst Wigforss pointed out that the "reflation policy" (eliminating the effects of the preceeding "deflation") had been the characteristic feature of monetary and exchange rate policy in recent years. The sterling peg in 1933 was not a departure from the directives; the fixed exchange rate to the pound implied that the level of Swedish wholesale prices was linked to the slow increase in British wholesale price, which facilitated "reflation". ${ }^{40}$

\footnotetext{
${ }^{38}$ Landgren (1960, p.13).

${ }^{39}$ Ibid, p. 2

${ }^{40}$ Ibid, p. 3
} 
In conclusion, with the adoption of the bill in May 1937, the primary goal of Swedish monetary policy again was framed as maintaining a stable price level. However, this was not the only goal set up for the Riksbank since other goals were advocated as well including a stable economy and full employment of the country's productive resources. As these objectives might conflict with maintenance of a stable price level, they presumably were secondary considerations. ${ }^{41}$ However, the government stressed the necessity of synchronizing economic and monetary measures and stated that the Riksbank, in choosing the means to accomplish its policy, should act in cooperation with the government, that is coordinate its measures with fiscal policy.

The ideas expressed by the Minister of Finance in 1937 should properly be seen as laying the foundations for the type of stabilization policy implemented in Sweden after World War II. Thus in 1937, when the Swedish monetary program had become a complete economic program for the country, this marked the beginning of the end of the monetary program of price stability. It became part of a more general macroeconomic policy package.

\subsection{Evaluation by Economists}

The policy of the Riksbank was closely followed, commented on and criticized by university economists. Initially, that is in the Fall of 1931, they were all in favor of the monetary program of 1931, although they did not share exactly the same view. Eventually, the economics profession split up into two groups, one favorable towards price stabilization, one critical of the monetary program.

The first group consisted of the older generation of economists, influenced by the monetary events of World War I. They were liberal in their general outlook and critical of government intervention. Cassel, Heckscher and Lindahl belonged to this group. They remained throughout the 1930s proponents of price stabilization and turned into critics of the new ideas of the younger generation.

The second group was made up of the new generation of economists that was making its way in the 1930s. They were influenced by the high and persistent unemployment of the 1930s. To them the challenge was to develop theories and policies to reduce unemployment and the fluctuations of the business cycle. They became early proponents of "active" countercyclical policies. This group was later termed the Stockholm School. ${ }^{42}$

\footnotetext{
${ }^{41}$ This is also the opinion by Lester $(1939$, p. 238).

${ }^{42}$ The diverging views on macroeconomic issues between the old and young generation of Swedish economists in the 1930s is dealt with in the introduction of Jonung (1992). Cassel's and Heckscher's resistance towards "the new economics" is examined by Carlson (1992).
} 
Bertil Ohlin and Gunnar Myrdal were the most prominent members of the Stockholm School. Gunnar Myrdal prepared a report for Ernst Wigforss budget of 1933 giving the theoretical foundations of a countercyclical fiscal policy. Ohlin suggested at an early stage various government measures to counteract unemployment. In December 1933 he reviewed the policy of the Riksbank in an article with the title "The Inadequacy of Price Stabilization". Here Ohlin was of the opinion that the Riksbank had failed in preventing a fall of wholesale and consumer prices. In addition, the price stabilization program had not prevented a decline in demand, in production, in real national income and in domestic investment according to Ohlin (1933). According to him:

"on the whole, then, we may say that, when once a depression has set in, a reduction in the quantities produced and marketed can very easily take place without being materially reflected in the index numbers presenting the average wholesale or retail price level."

On the other hand, Ohlin (1933, p. 264) thought that the monetary program had been beneficial to Sweden by preventing a further decline in prices. "The fatal spiral of deflation was avoided in Sweden." However, in his conclusions Ohlin thought price stabilization was insufficient. Instead, he recommended a policy aiming at "as full and regular utilization of the productive forces as possible." Ohlin thus proposed employment stabilization rather than price stabilization.

6. What was overloooked and what can be learnt?

The introduction of the monetary program in 1931 aiming at price stability raises several questions regarding the practical implementation of such a strategy. Here we are interested in the question: viewed in hindsight, did the Swedish experiment with price-level targeting overlook any issues that are of major concern today?

The modern view on optimal delegation of monetary policy may be summarized in three recommendations. First, the political authorities should define a clear goal for monetary policy, preferably price stability. This goal should be given a legal backing. Second, the central bank should be given operational independence in order to be able to fulfil the goal assigned by the political authorities. Third, the central bank should be held accountable to the political bodies for the conduct of monetary policy.

The monetary program adopted in 1931-32 can be regarded as setting a price-level target for a goal-dependent but instrument-independent central bank. The Riksdag stressed that the Riksbank should be given no directions as to its monetary policy beyond such as indicated by 
the objective of that policy. However, the program was not given a backing in terms of a new central bank legislation.

Although the original goal of stable prices was maintained throughout the 1930s, adjustments were made and additional goals were added by requests from the Parliament and the Minister of Finance as the depression worsened. In 1932 the goal to preserve the domestic purchasing power of the krona was adjusted as both import prices and domestic market prices were allowed to increase. The Riksbank was also asked to keep interest rates as low as possible without jeopardizing the monetary policy objective. In 1933 the Riksbank was asked to "intervene more actively" and "link" its monetary policy measures with fiscal policy measures to combat unemployment. In 1937 the Riksbank, in addition to the primary target to preserve a stable price level, was given other goals like aiming for full employment.

As pointed out by King (1996), any monetary policy regime can be described as a choice of an ex ante inflation target and an optimal response to temporary shocks.

One important issue is how fast the central bank should disinflate (or inflate) the economy in order to reach price stability. The effect on inflation and output, when a central bank announces that it intends to pursue price stability, will depend on how quickly expectations adjust to the new strategy.

A fully credible change to a regime of price stability means that private sector expectations are consistent with the new target. Credibility effects were considered in the Swedish experiment (although the word "credibility" was not explicity used), most notably by Heckscher who emphasized the role of "confidence". As demonstrated above, the decision not to return to the price level of 1928 was based on such considerations, which could be cast in a modern "credibility" framework.

Another issue in present debate on inflation targeting concerns the central bank's reaction function. A monetary policy rule can be defined as a "prescribed guide for monetary policy conduct", see for example Svensson (1998). As emphasized in the recent literature on inflation targeting, an optimal policy rule implies that the central bank's instrument, the short term interest rate, responds to variables which are useful for predicting future inflation, like inflation and the output gap. In practice, the part played by the inflation forecast is so vital that it resembles an intermediate target for inflation targeting central banks, see King (1994) and Svensson (1997a).

Central banks today should thus pursue monetary policy so that the inflation forecast for an appropriate horizon is in line with the inflation target. We have not found any references to 
explicit forward looking policy rules used in the 1930s by the Riksbank. Some of the Swedish economists were insightful as to the use of forecasts, but in practice it seems as if the Riksbank and its principals were primarily concerned with the behavior of the actual price level. The lack of any expertise on forecasting within the Riksbank may account for this state of affairs.

However, it may also be argued that a credible monetary policy that targets a price level or inflation rate need not be forward looking to be succesful. All that is necessary is a correctly specified feedback rule that is understood and believed. Simple instrument rules like the Taylor rule (see Taylor (1993)) relates the instrument only to actual inflation and the current output gap.

It is also clear that inflation targeting central banks are not relying solely on model based econometric forecasts using stylized models. Modern inflation reports cover detailed assesments of international inflation and economic activities, domestic demand relative to supply, other cost shocks and transitory effects, and inflation expectations as well.

From these perspectives, the Swedish authorities in the early 1930s were pioneers as they pointed out that so many factors have to be considered that one can hardly have a simple and formal rule for monetary policy. The Riksbank was also concerned with monitoring various price indices, discussing temporary factors and seasonal effects in a relatively modern way, although no inflation forecasts were made.

In 1931 the fears of inflation expressed when Sweden left the gold standard was replaced by a clear concern of continued deflation. The strength of the downward price effects in the global economy had probably been underestimated. By raising wholesale prices, while maintaining the retail price level, it was hoped to correct the perceived disequilibrium between wholesale prices and the cost of living index that had developed 1928-31, before the Bank began to stabilize prices. Although continued deflation should be resisted just as strongly as inflation, some recovery in prices was desirable, though not a return to a "unduly distant" price level.

This part of the program was successfully implemented. In 1937 wholesale prices were close to the level at the end of 1928, while the consumer price index had been relatively stable since 1931. This suggests that the price level target contributed to a low variability of consumer prices during the recovery from the depression. An important lesson from the early Swedish experience is that a price stability target can be used to raise inflation expectations when there are widespread fears of deflation. 
7. Why did price level targeting in Sweden come to an end?

The monetary program of 1931-32 was developed in a pre-Keynesian world where the dominating view held that monetary policy was effective in influencing the movement of prices. The depression that started in Sweden in 1930-31 and reached its trough in 1932-33 ended the adherence to the gold standard and opened simultaneously for new views and theories concerning the role of fiscal policies. The government budget was openly underbalanced and requests were made that monetary and fiscal polices should be coordinated.

As the depression deepended, price level targeting was considered necessary but not sufficient to bring Sweden out of the depression. The monetary program was viewed as arresting the deflationary process but not as adequate in raising production and employment. Instead, monetary policy should be coordinated with fiscal policy to stabilize the macroeconomy. This view eventually became the official policy position. It spelled the demise of price level targeting and the subordination of monetary policy in the post World War II-period. 


\section{References}

Andersson, Krister and Claes Berg, 1995, The inflation target in Sweden, in Targeting Inflation, ed. Andrew Haldane, Bank of England.

Bernanke, Ben S., 1995, The Macroeconomics of the Great Depression: A comparative approach. Journal of Money, Credit and Banking, Vol 27, no 1.

Bernanke, Ben S. and Frederic S. Mishkin, 1997, Inflation Targeting: A New Framework for Monetary Policy? Journal of Economic Perspectives 11, 97-116.

Carlson, Benny, 1992, The Long Retreat: Gustav Cassel and Eli Heckscher on the 'New Economics' of the 1930s, chapter 10 in L. Jonung, ed., Swedish Economic Thought. Explorations and Advances, Routledge, London.

Cassel, Gustav, 1941, I förnuftets tjänst (In the service of reason), Natur och Kultur, Stockholm. (Cassel's autobiography).

Debelle, Guy and Stanley Fischer, 1994, How Independent Should a Central Bank Be?, in Goals, Guidelines and Constraints Facing Monetary Policymakers, ed. Jeffrey Fuhrer, Federal Reserve Bank of Boston.

Dugay, Pierre, 1994, Some Thoughts on Price Stability versus Zero Inflation, Working Paper, Bank of Canada. Presented at the conference on Central Bank Independence and Accountability, Università Bocconi, Milan, March, 1994.

Eichengreen, Barry, 1992, Golden Fetters. The Gold Standard and the Great Depression, 1919-1939, Oxford University Press: New York.

Fischer, Stanley, 1994, Modern Central Banking, in Forrest Capie et al., The Future of Central Banking, Cambridge University Press.

Fischer, Stanley, 1996, Why are Central Banks Pursuing Long-run Price Stability?, in Achieving Price Stability, Federal Reserve Bank of Kansas City Symposium Series.

Fisher, Irving, 1934, Stable Money, Adelphi Company, New York

Fischer, Irving, 1937, The Lessons of Monetary Experience, Allen and Unwin, London.

Fregert, Klas, 1993, Erik Lindahl’s Norm for Monetary Policy, chapter 8 in L. Jonung, ed., Swedish Economic Thought. Explorations and Advances, Routledge, London.

Fregert, Klas and Lars Jonung, 1996, Inflation and Switches between Specie and Paper Standards in Sweden 1668-1931: A Public Finance Interpretation, Scottish Journal of Political Economy, September, no 4.

Friedman, Milton, and A.J. Schwartz, 1963, A monetary history of the United States, 18671960. Princeton: Princeton University Press. 
Goodhart, Charles and José Vinals, 1994, Strategy and Tactics of Monetary Policy: Examples from Europe and the Antipodes, in Jeffrey Fuhrer, ed., Goals, Guidelines and Constraints Facing Monetary Policymakers, Federal Reserve Bank of Boston.

Haldane, Andrew G., ed., 1995, Targeting Inflation, Bank of England, London.

Hammarskjöld, Dag, 1935, Centralbankerna i nutidens ekonomiska liv, (Central Banks in Present Economic Environment), Svenska Bankföreningen, Stockholm.

Johnson, Manuel, H. and Robert E. Keleher, 1996, Monetary Policy, A Market Price Approach, Quorum books, Westport.

Jonung, Lars, 1979a, Cassel, Davidson and Heckscher on Swedish Monetary Policy. A Confidential Report to the Riksbank in 1931, Economy and History, vol. XXII, no. 2, 85-101.

Jonung, Lars, 1979b, Knut Wicksell's Norm of Price Stabilization and Swedish Monetary Policy in the 1930s, Journal of Monetary Economics, vol. 5, 459-496.

Jonung, Lars, 1981, The Depression in Sweden and the United States: A Comparison of Causes and Policies, in Karl Brunner, ed. The Great Depression Revisited, Martinus Nijhoff, Boston.

Jonung, Lars, ed., 1992, The Stockholm School of Economics Revisited, Cambridge University Press, Cambridge.

King, Mervyn A., 1994, Monetary Policy in the UK, Fiscal Studies 15, No. 3, 109-128.

King, Mervyn A., 1996, How Should Central Banks Reduce Inflation? - Conceptual Issues, in Achieving Price Stability, Federal Reserve Bank of Kansas City Symposium Series.

Kjellström, Erik T.H., 1934, Managed Money: The Experience of Sweden, New York: Columbia University Press.

Landgren, Karl-Gustav, 1960, Den 'nya ekonomien’i Sverige. J.M. Keynes, E. Wigforss, B. Ohlin och utvecklingen 1927-39, Uppsala.

Leiderman, Leonardo, and Lars E.O. Svensson, eds., 1995, Inflation Targets, CEPR, London.

Lester, Richard A., 1937, Sweden's Experience with 'Managed Money', Supplement to Index, January, 1-31.

Lester, Richard A., 1939, Monetary Experiments, Early American and Recent Scandinavian, Princeton, Princeton University Press.

Lindahl, Erik, 1933, Consumer Price Index, Sveriges Riksbank, offprint from Ekonomisk Tidskrift, no. 3 .

Lindahl, Erik, 1937, International Economic Reconstruction Realized through Rational Management of Free Currencies, in Fischer (1937). 
Magnusson, Lars, 1993, The Economist as Popularizer: The Emergence of Swedish Economics 1900-30, in Lars Jonung, ed., Swedish Economic Thought. Explorations and Advances, Routledge, London.

Memorandum by the Swedish Delegation on the Monetary Policy of Sweden, 1933. League of Nations. Monetary and Economic Conference, London, 21 June 1933.

Ohlin, Bertil, 1932, Sweden's Monetary Policy. Index, vol. VII, no. 81 (September), 268-278.

Ohlin, Bertil, 1933, The Inadequacy of Price Stabilization. Some Experience from the Swedish Experiment, Index, 252-65.

Ohlin, Bertil, 1934, Knut Wicksell: Father of the Swedish Monetary Experiment, Economic Forum, 159-67.

Svensson, Lars E.O., 1997a, Inflation Forecast Targeting: Implementing and Monitoring Inflation Targets, European Economic Review, 41, 1111-1146.

Svensson, Lars E.O., 1997b, Price Level Targeting vs Inflation Targeting: A Free Lunch?, Journal of Money, Credit and Banking, forthcoming, NBER Working Paper No. 5719

Svensson, Lars E.O., 1998, Inflation Targeting as a Monetary Policy Rule, in this issue.

Taylor, John B., 1993, Discretion versus Policy Rules in Practice, Carnegie-Rochester Conference Series on Public Policy 39, 195-214

Wicksell, Knut, 1965, Interest and Prices, New York. Augustus M. Kelley. 
Figure 1. Wholesale price index and the consumer price index of the Riksbank, 1928-1938.

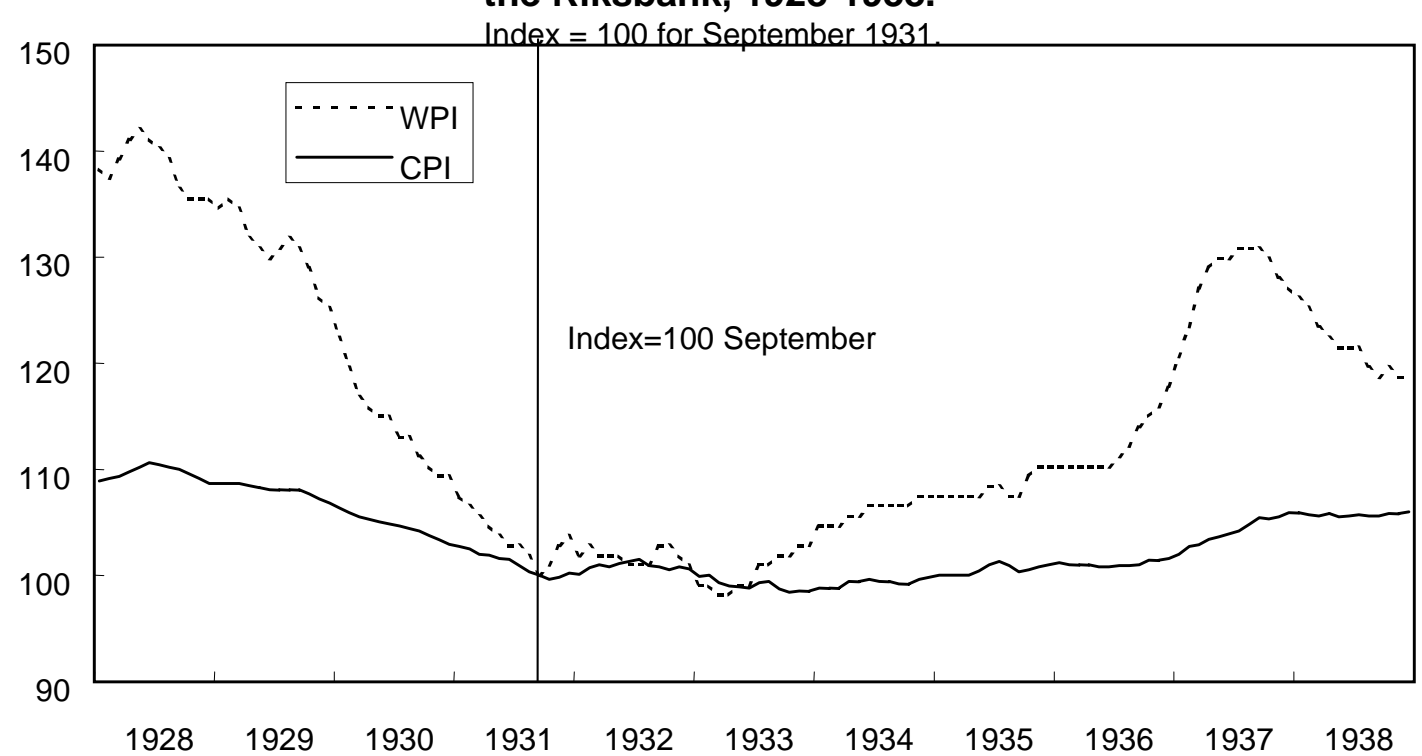

Comment: The quarterly cost-of-living index for 1928-1930 has been interpolated and linked to the monthly consumer price index of the Riksbank starting in January 1931 Source: The Riksbank.

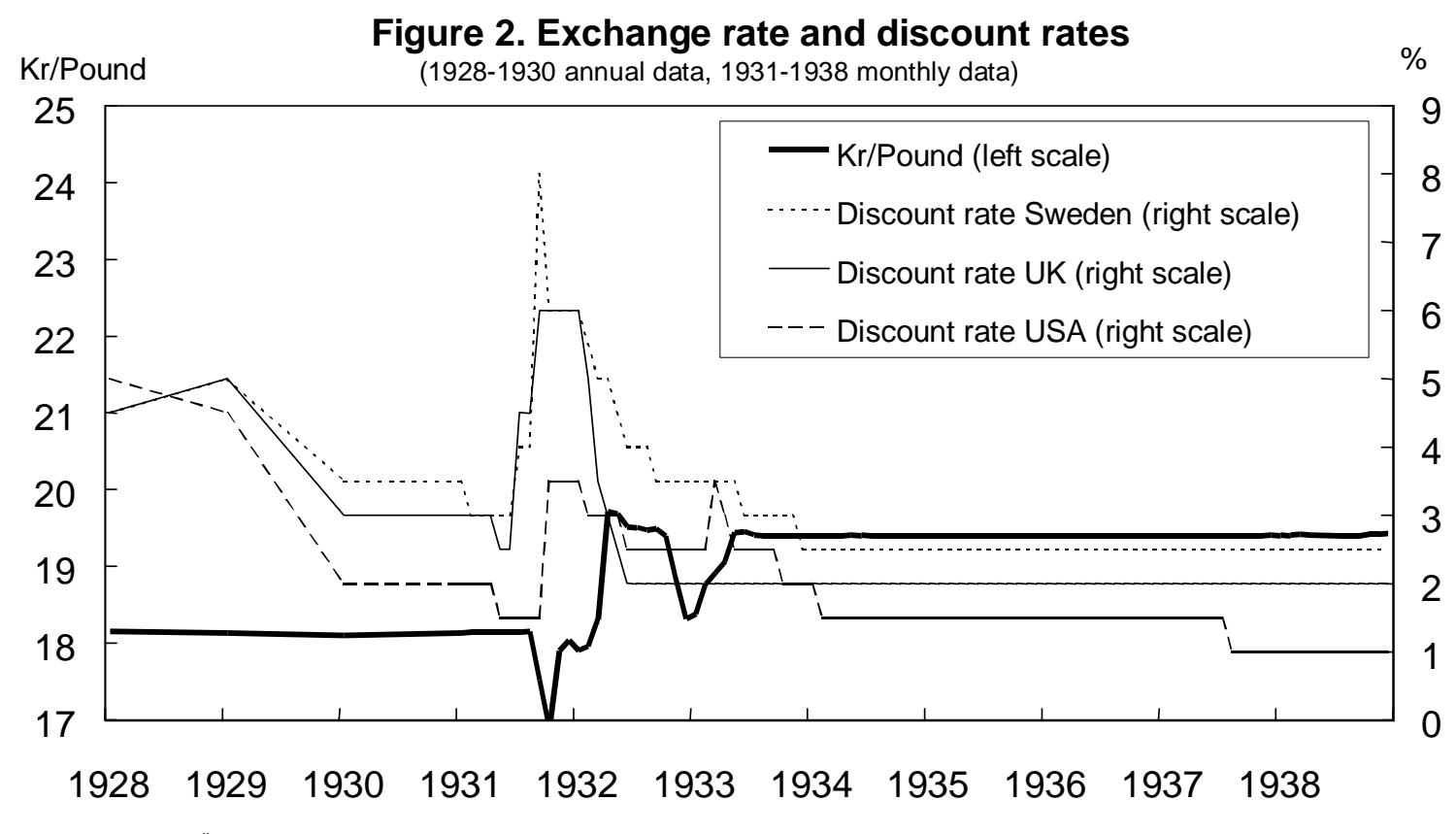

Source: Ekonomisk Översikt 1932-1940 
Figure 3. Unemployment among union members and industrial production 1928-1938.

Index $1928=100$

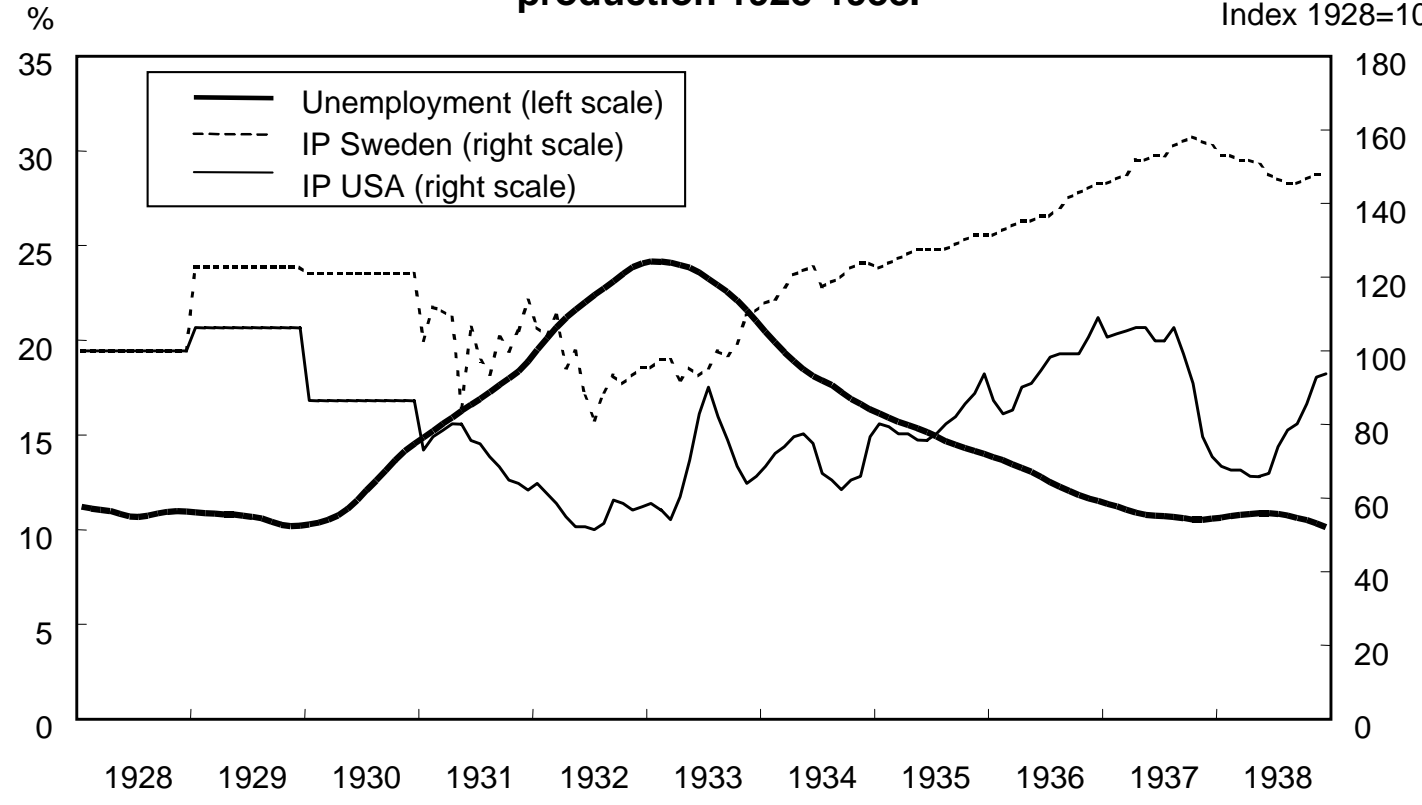

Comment: The unemployment is calculated as 12-months moving average. averaqe 


\section{Appendix A.}

Table A1. The Questionnaire of the Riksbank of October 1931.

I. A. Under which international conditions would it be appropriate for the Swedish monetary system to be tied to monetary conditions in other countries.

B. Which arguments can be advanced for tying the krona

1) to an international currency, primarily to a gold standard, and

2) to a given foreign currency?

C. Which should be the basic conditions for a transition or return to such a system? Should the exchange rate of the krona be set equal to the old parity to gold, or to a given foreign currency, as for example the pound, or to some other rate, more recently attained?

D. Should such a transition be instituted as a temporary step, subject to possible changes, or should it come about in a single once-and-for-all reform?

E. Which norms should guide the discount policy and the foreign exchange policy of the Riksbank in lieu of such a transition or return?

F. How should domestic price stability be realized under present circumstances? Should the goal of price stabilization be expressed in terms of wholesale or retail prices or in terms of the cost of living, in import and/or export prices, or in still some other way?

II. Which means are available to the Riksbank to accomplish
a) a transition to
b) and preservation of the proposed system?
Is there a need for any powers that the Riksbank
a) presently lacks or
b) presently does not use?

III. Which other questions should preferably be considered in connection with the future organization of the Swedish monetary system?

Source: Jonung (1979a). 